\title{
KETAHANAN PANGAN RUMAH TANGGA DI JAWA BARAT: ANALISIS DATA SUSENAS 2012
}

\author{
Heryanah \\ Badan Pusat Statistik Kota Sukabumi \\ Korespondensi: Heryanah (e-mail: heryanah@bps.go.id)
}

\begin{abstract}
Abstrak
Tujuan penelitian ini adalah menggambarkan kondisi ketahanan pangan rumah tangga di Provinsi Jawa Barat tahun 2012 dengan data Susenas dan menggunakan regresi order logistik. Selain itu, penelitian ini juga mencoba mencari faktor-faktor yang memengaruhi ketahanan pangan rumah tangga di Jawa Barat dengan sepuluh variabel independen (dummy perkotaan, dummy jenis kelamin, dummy status perkawinan, umur kepala rumah tangga, banyaknya jumlah anggota rumah tangga, rata-rata lama sekolah dari kepala rumah tangga, dummy kerja atau tidak, pengeluaran per kapita rumah tangga, dummy kelayakan sanitasi, dan dummy kondisi kumuh). Dari hasil penelitian diketahui bahwa tahun 2012 sebanyak 34 persen rumah tangga di Jawa Barat tergolong rumah tangga tahan pangan. Proporsi dari rumah tangga yang rawan pangan juga masih tinggi di provinsi ini, yaitu 15 persen dari total populasi. Selain itu, kesepuluh independen variabel secara statistik signifikan memengaruhi ketahanan pangan rumah tangga di Jawa Barat.
\end{abstract}

Kata kunci: ketahanan pangan, rumah tangga, data Susenas

\section{HOUSEHOLD FOOD SECURITY IN WEST JAVA: ANALYSIS BY USING SUSENAS DATA 2012}

\begin{abstract}
The objective of this research is to illustrate the condition of food security of household level in West Java Province in 2012 by using Susenas data and employing order logistics regression. Moreover, this research tries to explore the factors that affect the household food secure with using 10 independent variables (city dummy, sex dummy, marriage status dummy, age of the household head, the number household, mean years of school of the household head, work dummy, per capita mean expenditure, sanitation dummy, and slum area dummy). In 2002, the number of household in West Java Province with the level of food secure is about 34 percent of total population, however, the number of household with the level of food insecure still high, is about 15 percent of the total population. The output of the regression shows that all the independent variables are statistically significant influence the household food secure.
\end{abstract}

Keywords: food security, household, Susenas data

1 Tulisan ini merupakan revisi dari karya tulis ilmiah diklat fungsional (Heryanah, 2014). 


\section{Pendahuluan}

Masalah pangan bukan hanya menjadi pokok perhatian pemerintah pusat, tetapi juga bagi Pemerintah Daerah Jawa Barat yang terkenal sebagai salah satu provinsi dengan potensi agrarianya. Berdasarkan data dari Badan Ketahanan Pangan Daerah (BKPD) Provinsi Jawa Barat, masih terdapat beberapa daerah kabupaten/kota di provinsi ini yang berstatus rawan, bahkan sangat rawan pangan.

Sebagai kebalikan dari rawan pangan (food insecure), tahan pangan (food security) merupakan kondisi yang diartikan sebagai tersedianya pangan dalam jumlah yang cukup, terdistribusi dengan harga terjangkau, dan aman dikonsumsi bagi setiap warga untuk menopang aktivitasnya sehari-hari sepanjang waktu. Dari definisi tersebut, dapat disimpulkan bahwa ketahanan pangan adalah konsep yang integratif antara keberadaan, distribusi, dan konsumsi pangan. Sementara itu, akan timbul kerawanan pangan ketika kondisi pangan yang dialami daerah, masyarakat, atau rumah tangga pada waktu tertentu tidak cukup untuk memenuhi kebutuhan fisiologis bagi pertumbuhan dan kesehatan masyarakat. Kerawanan pangan tersebut dapat terjadi berulang-ulang setiap waktu (kronis) dan dapat pula terjadi akibat keadaan darurat, seperti bencana alam maupun bencana sosial.

Walaupun program peningkatan produksi pangan menunjukkan keberhasilan, jaminan tersedianya pangan dalam jumlah yang cukup, distribusi dan stabilitas pengadaan tentu menjadi permasalahan lain yang harus diatasi. Selain itu, pola konsumsi dari masyarakat juga tentu perlu terus ditingkatkan.

Pembahasan ketahanan pangan tidak hanya terkonsentrasi pada ketahanan pangan daerah dan wilayah, tetapi juga mencakup ketahanan pangan rumah tangga. Ketahanan pangan rumah tangga tidak hanya menyangkut masalah ketersedian pangan, tetapi juga masalah daya beli dari rumah tangga. Hal ini karena peningkatan derajat ketahanan pangan yang tinggi akan sulit dicapai walaupun jumlah pangan melimpah dan pengadaannya di suatu daerah stabil jika rumah tangga tidak mampu mengaksesnya karena minimnya daya beli.

Penelitian ini fokus pada penelitian ketahanan pangan rumah tangga. Oleh karena itu, ketahanan pangan wilayah dan daerah tidak akan dibahas di sini. Secara umum, tujuan penelitian ini adalah menggambarkan kondisi ketahanan pangan rumah tangga di Jawa Barat. Secara khususnya, tulisan ini ingin mengeksplorasi faktor-faktor sosial ekonomi yang memengaruhi ketahanan pangan rumah tangga di Jawa Barat dengan data Susenas tahun 2012 dan metode order logistic regression.

\section{Kajian Literatur}

Pangan merupakan salah satu masalah krusial yang pengadaannya harus mengikutsertakan pemerintah secara aktif. Dengan terbitnya UU No. 7 Tahun 1996 tentang Pangan, pemerintah berusaha mengatur semua masalah yang berhubungan dengan pangan, termasuk di dalamnya masalah ketahanan pangan.

Konsep ketahanan pangan di dalam UU tersebut didefinisikan sebagai kondisi terpenuhinya pangan bagi setiap rumah tangga, yang tercermin dari tersedianya pangan yang cukup baik jumlah maupun mutunya, aman, merata, dan terjangkau. Konsep ketahanan pangan ini mengadopsi definisi yang dikeluarkan oleh Food and Agriculture Organization (FAO) yang tahun 1996 menjabarkan adanya empat unsur yang harus dipenuhi dalam rangka mencapai kondisi ketahanan pangan. Keempat unsur itu adalah cukupnya ketersediaan pangan, stabilitas ketersediaan pangan, akses terhadap pangan, dan kualitas pangan. 
Selain FAO, beberapa lembaga juga memberikan definisi ketahanan pangan, seperti World Bank (1996) yang menyatakan bahwa ketahanan pangan adalah akses oleh semua orang pada segala waktu atas pangan yang cukup untuk kehidupan yang sehat dan aktif. Kemudian Oxfam (2001) menjelaskan bahwa ketahanan pangan adalah kondisi ketika setiap orang dalam segala waktu memiliki akses dan kontrol atas jumlah pangan yang cukup dan kualitas yang baik demi hidup yang aktif dan sehat. FIVIMS (Food Insecurity and Vulnerability Information and Mapping Systems, 2005) menjabarkan konsep ketahanan pangan sebagai kondisi ketika semua orang pada segala waktu secara fisik, sosial, dan ekonomi memiliki akses pada pangan yang cukup, aman, dan bergizi untuk pemenuhan kebutuhan konsumsi (dietary needs) dan pilihan pangan (food preference) demi kehidupan yang aktif dan sehat.

Kondisi ketahanan pangan rumah tangga ditentukan oleh kemampuan rumah tangga untuk memenuhi kebutuhan pangan mereka. Masalah kemampuan ini berhubungan juga dengan masalah kemiskinan. Ketidakmampuan rumah tangga dalam pemenuhan pangan tidak hanya dilihat dari pemenuhan secara kuantitas, tetapi juga termasuk masalah kualitas pangan.

Sehubungan dengan pentingnya masalah ketahanan pangan rumah tangga ini, ada beberapa ahli maupun institusi yang mengembangkan indikator untuk mengukur tingkat ketahanan atau kerawanan pangan rumah tangga. Secara umum, terdapat tiga pengukuran ketahanan pangan rumah tangga yang banyak digunakan untuk tujuan tersebut. Berikut adalah penjelasan tentang ketiganya.

1. Pola pangan harapan, yaitu metode yang utamanya digunakan sebagai perencanaan konsumsi, kebutuhan, dan ketersediaan pangan di suatu wilayah. Metode ini berdasarkan pada konsumsi energi dan zat gizi total, persentase energi dan gizi aktual, serta skor kedua variabel tersebut.
2. AHFSI (Aggregate Household Food Security Index) yang dikembangkan oleh FAO tahun 1996 dan pengukurannya berdasarkan konsumsi kalori rumah tangga.

AHFSI didapat berdasarkan rumus:

$100-[H(G+(1-G) I p)+1 / 2 s\{1-H(G+(1-G)$ Ip)\}] 100

Keterangan:

$\mathrm{H}=$ Nilai Head Count Ratio, yaitu proporsi penduduk yang mempunyai konsumsi kalori kurang dari standar kecukupan kalori nasional

$\mathrm{G}=$ Food Gap, yaitu proporsi gap antara konsumsi kalori rumah tangga terhadap standar kecukupan kalori nasional Ip = Ukuran ketimpangan pada distribusi food gap $\mathrm{s}=$ Koefisien variasi dari konsumsi kalori rumah tangga.

3. Pangsa pangan, yaitu indikator ketahanan pangan pada tingkat rumah tangga yang diukur dengan klasifikasi silang dua indikator ketahanan pangan, yaitu pangsa pengeluaran pangan dan kecukupan konsumsi energi (Kkal) (Jonsson \& Toole, 1991). Berikut adalah empat kategori rumah tangga menurut tingkat ketahanan pangan.

a. Tahan pangan (pangsa pangan $<60$ $\%$, kecukupan energi $>80 \%$ )

b. Rentan pangan (pangsa pangan $>=60$ $\%$, kecukupan energi $>80 \%$ )

c. Kurang pangan (pangsa pangan $<60$ $\%$, kecukupan energi $<=80 \%$ )

d. Rawan pangan (pangsa pangan $>=60$ $\%$, kecukupan energi $<=80 \%$ ). 


\section{Data dan Metode Penelitian}

\section{Data}

Studi ini menggunakan data Susenas tahun 2012. Susenas adalah data sosial ekonomi nasional yang dikumpulkan oleh Badan Pusat Statistik (BPS) secara periodik sejak tahun 1963. Jika dilihat dari sejarah perkembangan Susenas, pada awalnya survei ini hanya mencakup 5 provinsi di Pulau Jawa dengan jumlah sampel hanya sebanyak 16.000 rumah tangga. Sejalan dengan meningkatnya kesadaran terhadap pentingnya data ini, yang digunakan juga untuk menghitung data kemiskinan dan ketimpangan di Indonesia, sejak tahun 1982 Susenas mencakup seluruh provinsi (termasuk Provinsi Timor Timur saat masih bergabung dengan Indonesia) dan jumlah sampelnya juga mengalami kenaikan tiap tahunnya.

Susenas mengumpulkan 2 jenis data, yaitu data KOR dan Modul. Yang dimaksudkan dengan KOR adalah kumpulan pertanyaanpertanyaan yang bersifat umum yang selalu ditanyakan setiap tahun, sedangkan Modul adalah pertanyaan-pertanyan khusus yang sesuai dengan topiknya dan lebih rinci yang dilakukan 3 tahun sekali untuk setiap topik, yaitu Modul Konsumsi, Modul Sosial Budaya dan Pendidikan, serta Modul Perumahan dan Kesehatan. Susenas KOR dilaksanakan setiap tahun untuk mengumpulkan data individu dan rumah tangga terkait dengan kesehatan, pendidikan, pekerjaan, dan pengeluaran. Pengeluaran yang dicakup di dalam data pengeluaran konsumsi diklasifikasikan ke dalam kelompok makanan dan nonmakanan. Konsumsi pengeluaran juga merekam apakah konsumsi itu melalui pembelian, produksi sendiri, atau pemberian dari pihak lain. Barang dan jasa yang bersumber dari produksi sendiri ataupun dari pihak lain direkam dengan cara mengimputasi, artinya barang/jasa hasil produksi sendiri atau pemberian dari orang lain tersebut diperkirakan nilainya berdasarkan harga pada umumnya.

Pada penelitian ini, data Susenas yang digunakan hanya Susenas Provinsi Jawa Barat saja. Jumlah sampel Susenas untuk Provinsi Jawa Barat tahun 2012 adalah 22.470 rumah tangga.

\section{Metode Penelitian}

Dalam statistik, tujuan dasar dari regresi adalah melihat suatu hubungan antara satu variabel dengan variabel-variabel lainnya dan mencari model yang terbaik untuk menjelaskan hubungan tersebut. Metode regresi berdasarkan jenis variabel dependennya dapat dibedakan menjadi regresi linier dan regresi logistik. Jika dalam regresi linier, variabel dependennya diasumsikan bersifat kontinu, sedangkan dalam regresi logistik, variabel dependennya bersifat diskrit (Gujarati, 2003).

Pada penelitian ini, variabel dependennya bersifat diskrit/kategorikal berskala ordinal sehingga model regresi logistik merupakan metode yang paling sesuai digunakan. Regresi logistik atau kadang disebut model logit merupakan salah satu analisis regresi yang digunakan untuk menganalisis hubungan antara variabel dependen dengan variabel independen. Dalam hal ini, variabel dependen bersifat polikotomus dengan skala ordinal digunakan untuk memprediksi probabilitas kejadian suatu peristiwa dengan mencocokkan data pada fungsi logit kurva logistik (Praptono, 2009).

Dalam regresi linier nilai $\mathrm{E}(\mathrm{Y} \mid \mathrm{x})$ dinyatakan dalam bentuk berikut.

$$
E(Y \mid x)=\beta_{0}+\beta_{1} x
$$

Nilai $E(Y \mid x)$ untuk sembarang nilai $x$ terletak pada selang $-\infty<E(\mathrm{Y} \mid \mathrm{X})<\infty$

Dalam regresi logistik, nilai $\mathrm{E}(\mathrm{Y} \mid \mathrm{x})$ berada dalam selang $[0,1]$. 
Bentuk model regresi logistik adalah sebagai berikut.

$$
\begin{aligned}
& \pi\left(x_{i}\right)=\frac{e^{\beta_{0}+\beta_{1} x_{1 i}+\cdots+\beta_{p} x_{p i}}}{1+e^{\beta_{0}+\beta_{1} x_{1 i}+\cdots+\beta p \beta_{p i}}} \\
& i=1, \ldots, n X=\left(X_{1}, \ldots, X_{p}\right)
\end{aligned}
$$

Di bawah ini adalah bentuk khusus model regresi logistik dengan satu variabel bebas $x$.

$$
\pi(x)=\frac{e^{\beta_{0}+\beta_{1} x}}{1+e^{\beta_{0}+\beta_{1} x}}
$$

Persamaan di atas dapat ditulis sebagai berikut.

$$
\pi(x)=\frac{1}{1+e^{-\beta_{0}-\beta_{1} x}}
$$

Kendala dalam model peluang linier seperti pada persamaan di atas adalah nilai peluangnya dibatasi pada 0 dan 1 . Pemecahan terhadap masalah tersebut adalah mentransformasikan peluang menjadi oddsyangakan menghilangkan batas atasnya. Mengambil nilai logaritma dari odds akan menghilangkan batas bawahnya. Dengan demikian, untuk intepretasi regresi logistik, digunakanlah odd ratio atau kemungkinan.

Transformasi ini ditulis dalam bentuk $\pi(x)$ dan didefinisikan sebagai berikut.

Uji Statistik

$$
g(x)=\ln \left[\frac{\pi(x)}{1-\pi(x)}\right]=\beta_{0}+\beta_{1} x
$$

Uji statistik yang dilakukan pada penelitian ketahanan pangan rumah tangga ini terdiri atas hal-hal berikut ini.

a). Uji Multikolinieritas

Uji multikolinieritas adalah pengujian untuk mengetahui ada tidaknya hubungan yang linier atau korelasi antara variabel independen yang signifikan pada model regresi. b). Pengujian Parameter

Model yang telah diperoleh perlu diuji signifikansi pada koefisien $\beta$ terhadap variabel dependen, yaitu dengan uji serentak dan uji parsial.

\section{Uji Serentak}

Pengujian ini dilakukan umtuk memeriksa kemaknaan koefisien $\beta$ terhadap variabel dependen secara bersama-sama.

Hipotesis:

$$
\begin{aligned}
& H_{0}: \beta_{1}=\beta_{2}=\ldots=\beta_{k}=0 \\
& H_{1}: \text { paling sedikit ada satu } \beta_{k} \neq 0 ; k \\
& =1,2, \ldots, p
\end{aligned}
$$

LikelihoodRatio Test(LR)merupakan pengganti F-stat (uji serentak pada regresi linear) yang berfungsi untuk menguji apakah semua slope koefisien regresi variabel independen secara bersama-sama memengaruhi variabel dependen.

Statistik uji yang digunakan adalah statistik uji Wald.

$$
\mathrm{W}=\frac{\hat{\beta}_{k}}{S E\left(\hat{\beta_{k}}\right)}
$$

Daerah penolakan $\mathrm{HO}$ adalah $|W|>Z_{\alpha /}$ atau $\mathrm{W} 2>\mathrm{X} 2(\alpha, \mathrm{y})$ dengan derajat bebas $v$ atau nilai $p$-value $<\alpha$

\section{$\underline{\text { Uii Parsial }}$}

Pengujian ini dilakukan untuk memeriksa kemaknaan koefisien $\beta$ secara parsial menggunakan statistik uji.

$$
\begin{aligned}
& H_{0}: \beta_{k}=0 \\
& H_{1}: \beta_{k} \neq 0 ; k=1,2, \ldots, p
\end{aligned}
$$


Uji parsial untuk setiap variabel independen dilakukan dengan melihat Prob>chi2 dari tiap variabel independen.

\section{c). Uji Goodness of Fit}

Uji ini dilakukan untuk melihat seberapa baik suatu model dapat menjelaskan hubungan antara variabel dependen dengan variabel independennya. Pada regresi logistik, parameter yang dilihat untuk menguji Goodness of Fit adalah
Pseudo $R^{2}$, yaitu $R$-square tiruan yang digunakan karena tidak adanya padanan yang dapat mengganti $R$-square OLS pada model logit.

\section{Variabel Penelitian}

Penelitian ketahanan pangan rumah tangga di Jawa Barat ini terdiri atas satu variabel dependen dan sepuluh variabel independen. Tabel dan deskripsi dari variabelvariabel tersebut adalah sebagai berikut.

Tabel 1 Variabel yang Dipergunakan dalam Penelitan beserta Keterangannya

\begin{tabular}{|c|c|c|c|c|}
\hline No & Variabel & Sebagai & Jenis & Keterangan \\
\hline 1 & Ketahanan Pangan & Dependen & Kategorikal & $\begin{array}{c}0=\text { Rawan Pangan } \\
1=\text { Kurang Pangan } \\
2=\text { Rentan Pangan } \\
3=\text { Tahan Pangan }\end{array}$ \\
\hline 2 & Tipe Daerah & Independen & Kategorikal & $\begin{array}{c}0=\text { Perdesaan } \\
1=\text { Perkotaan }\end{array}$ \\
\hline 3 & Jenis Kelamin KRT & Independen & Kategorikal & $\begin{array}{c}0 \text { = Perempuan } \\
1 \text { = Laki-laki }\end{array}$ \\
\hline 4 & Status Perkawinan KRT & Independen & Kategorikal & $\begin{array}{c}0=\text { KRT tidak berstatus } \\
\text { menikah }\end{array}$ \\
\hline 5 & Usia KRT & Independen & Kontinu & - \\
\hline 6 & $\begin{array}{c}\text { Jumlah Anggota Rumah } \\
\text { Tangga }\end{array}$ & Independen & Kontinu & - \\
\hline 7 & $\begin{array}{c}\text { Rata-rata lama sekolah } \\
\text { KRT }\end{array}$ & Independen & Kontinu & - \\
\hline 8 & Status Bekerja dari KRT & Independen & Kategorikal & $\begin{array}{c}0=\text { Tidak Bekerja } \\
1=\text { Bekerja }\end{array}$ \\
\hline 9 & Pengeluaran per Kapita & Independen & Kontinu & - \\
\hline 10 & $\begin{array}{c}\text { Kondisi Sanitasi Rumah } \\
\text { Tangga }\end{array}$ & Independen & Kategorikal & $\begin{array}{c}0=\text { Sanitasi tidak layak } \\
1 \text { = Sanitasi layak }\end{array}$ \\
\hline 11 & $\begin{array}{c}\text { Kondisi Kumuh Rumah } \\
\text { Tangga }\end{array}$ & Independen & Kategorikal & $\begin{array}{c}0=\text { Rumah Tangga tidak } \\
\text { kumuh } \\
1=\text { RumahTangga kumuh }\end{array}$ \\
\hline
\end{tabular}

Sumber: Susenas 2012 (diolah) 
Tabel 2 Pembentukan Variabel Ketahanan Pangan Rumah Tangga berdasarkan Data Kalori dan Proporsi Pengeluaran Makanan

\begin{tabular}{ccc}
\hline \multirow{2}{*}{$\begin{array}{c}\text { Kategori kecukupan konsumsi } \\
\text { energi per unit ekuivalen dewasa }\end{array}$} & \multicolumn{2}{c}{ Pangsa pengeluaran pangan } \\
\cline { 2 - 3 } & $\begin{array}{c}\mathbf{6 0 \%} \text { pengeluaran total } \\
\text { (RENDAH) }\end{array}$ & $\begin{array}{c}\mathbf{8 0 \%} \text { pengeluaran } \\
\text { total (TINGGI) }\end{array}$ \\
\hline$>80 \%$ kecukupan energi (CUKUP) & Tahan pangan & Rentan pangan \\
\hline$\leq 80 \%$ kecukupan energi (KURANG) & Kurang pangan & Rawan pangan \\
\hline
\end{tabular}

Sumber: Jonsson dan Toole (1991)

\section{a. Variabel Dependen}

Yang menjadi variabel dependen dalam penelitian ini adalah ketahanan pangan rumah tangga. Data yang dipakai untuk membentuk variabel ketahanan pangan rumah tangga adalah data kalori yang dikonsumi rumah tangga dan data proporsi pengeluaran makanan terhadap total pengeluaran rumah tangga sebagaimana didefinisikan oleh Jonsson dan Toole (1991).

Dengan kategori ketahanan pangan rumah tangga seperti di atas, variabel dependen pada penelitian ini merupakan variabel kategorikal sehingga dibentuk ketentuan sebagai berikut.

$\mathrm{Y}=0$ jika rumah tangga rawan pangan

$Y=1$ jika rumah tangga kurang pangan

$Y=2$ jika rumah tangga rentan pangan

$Y=3$ jika rumah tangga tahan pangan.

b. Variabel Independen

Variabel independen yang digunakan dalam penelitian ini terdiri atas hal-hal berikut ini.

\section{Kategori daerah}

Kategori daerah merupakan tipe dari daerah tempat tinggal rumah tangga sampel penelitian. Pada penelitian ini akan dilihat apakah tempat tinggal merupakan faktor yang dapat digunakan untuk mengukur ketahanan pangan rumah tangga. Oleh karena itu, dibentuk dummy variabel sebagai berikut.

$$
\begin{array}{r}
\mathrm{X} 1=\quad 1 \text { jika daerah perkotaan } \\
0 \text { jika daerah perdesaan }
\end{array}
$$

\section{Jenis kelamin dari kepala rumah tangga}

Pada penelitian ini akan dilihat apakah ada pengaruh antara jenis kelamin dari Kepala Rumah Tangga (KRT) terhadap ketahanan pangan rumah tangga. Oleh karena itu, dibentuk dummy variable sebagai berikut.

$$
\begin{gathered}
\mathrm{X} 2=1 \text { jika KRT berjenis kelamin laki-laki } \\
0 \text { jika KRT berjenis kelamin } \\
\text { perempuan }
\end{gathered}
$$

\section{Status perkawinan dari kepala rumah tangga}

Variabel status perkawinan digunakan untuk melihat apakah ada pengaruh status perkawinan dari KRT terhadap ketahanan pangan rumah tangga yang bersangkutan. Kemudian dummy variabel dibentuk sebagai berikut. 
X3 = 1 jika KRT berstatus kawin

0 jika tidak

Usia dari kepala rumah tangga

Variabel ini merupakan variabel kontinu untukmelihat apakahusia dari KRT merupakan faktor yang memengaruhi ketahanan pangan rumah tangga.

\section{Banyaknya anggota rumah tangga}

Ini merupakan variabel kontinu. Apakah jumlah anggota rumah tangga merupakan salah satu faktor penentu kondisi ketahanan pangan rumah tangga?

\section{Rata-rata lama sekolah dari kepala rumah tangga}

Ini merupakan variabel kontinu. Apakah lamanya tahun pendidikan dari KRT memiliki andil terhadap kondisi ketahanan pangan rumah tangga?

Status bekerja dari kepala rumah tangga

X7 = 1 jika KRT berstatus bekerja

0 jika tidak

\section{Pengeluaran per kapita rumah tangga}

Pengeluaran per kapita rumah tangga adalah rata-rata pengeluaran per orang yang harus dikeluarkan rumah tangga dalam sebulan (dalam 00.000 rupiah).

\section{Kondisi sanitasi dari rumah tangga}

Ini merupakan variabel dummy dengan ketentuan sebagai berikut.

$$
\begin{gathered}
X 9=\quad 1 \text { jika kondisi sanitasi dari rumah } \\
\text { tangga sampel layak } \\
0 \text { jika tidak }
\end{gathered}
$$

\section{Kondisi 'kumuh' dari rumah tangga}

Ini merupakan variabel dummy dengan ketentuan sebagai berikut.

$$
\begin{gathered}
\text { X10 = } 1 \text { jika kondisi rumah tangga sampel } \\
\text { kumuh } \\
0 \text { jika tidak }
\end{gathered}
$$

\section{Hasil dan Pembahasan}

\section{Analisis Deskriptif}

Badan Ketahanan Pangan Daerah Provinsi Jawa Barat yang dibentuk berdasarkan Peraturan Daerah Nomor 22 Tahun 2008 menerbitkan Peta Ketahanan dan Kerentanan Pangan Indonesia atau Food Security and Vulnerability Atlas (FSVA) provinsi tahun 2011. FSVA mengacu pada tiga pilar ketahanan pangan yang berdasarkan Kerangka Konsep Ketahanan Pangan dan Gizi, yaitu ketersediaan pangan, akses terhadap pangan, dan pemanfaatan pangan.

FSVA mengindikasikan bahwa dalam hal ketersedian pangan, Provinsi Jawa Barat secara umum termasuk dalam kategori daerah swasembada pangan. Akan tetapi, jika ditinjau dari akses terhadap pangan, Provinsi Jawa Barat termasuk ke dalam lima provinsi (bersama dengan Provinsi Sulawesi Utara, Papua, DKI Jakarta, dan Sumatera Barat) dengan kondisi tingkat kemiskinan yang tidak mengalami perbaikan sejak tahun 2003. Masalah kondisi tingkat kemiskinan yang stagnan ini memengaruhi rumah tangga dalam mengakses kebutuhan pangan mereka.

Berikut ini adalah deskripsi mengenai kondisi ketahanan pangan rumah tangga di Provinsi Jawa Barat berdasarkan perhitungan pangsa pangan dari Maxwel dan AHFSI (FAO, 1996) menggunakan data Susenas tahun 2012. 
1. Pangsa Pangan

Dari Gambar 1 dapat dilihat bahwa pada 2012 sepertiga rumah tangga di Jawa Barat termasuk kategori rumah tangga yang tahan pangan. Namun, di sisi lain proporsi dari mereka yang termasuk kategori rawan pangan dan kurang pangan masih tergolong cukup tinggi, yaitu masing-masing sekitar 15 persen dari total rumah tangga di Jawa Barat. Sementara itu, proporsi terbesar di Jawa Barat adalah rumah tangga yang rentan pangan dengan proporsi sebesar 36 persen.
Jika dilihat berdasarkan kabupaten dan kota, secara umum proporsi terbanyak dari rumah tangga di kabupaten/kota tergolong rentan pangan. Kota Cimahi dan Kota Depok merupakan wilayah tingkat II dengan proporsi rumah tangga tahan pangannya terbanyak. Lebih dari setengah total rumah tangga di Kota Cimahi dan Depok termasuk kategori tahan pangan. Sementara itu, Kabupaten Tasikmalaya dan Kabupaten Bandung Barat merupakan kabupaten dengan proporsi rumah tangga yang tergolong rawan pangan terbanyak.

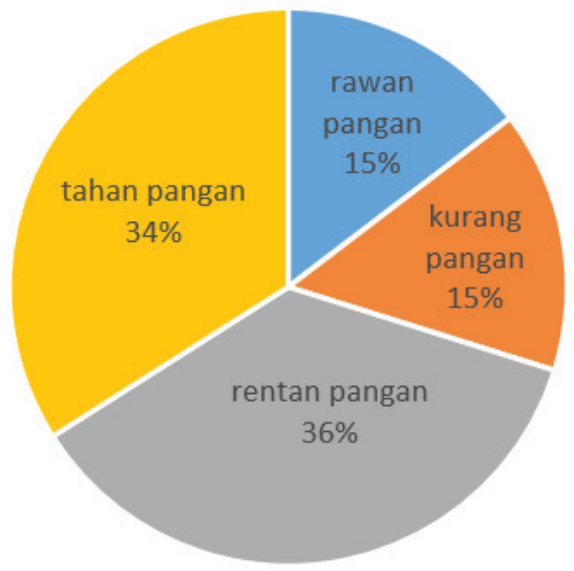

- rawan pangan

- kurang pangan

- rentan pangan

- tahan pangan

Sumber: Susenas (diolah)

Gambar 1 Persentase Rumah Tangga dengan Kategori Ketahanan Pangan di Jawa Barat Tahun 2012 
Tabel 3 Persentase Rumah Tangga dengan Kategori Ketahanan Pangan di Jawa Barat berdasarkan Kabupaten/Kota Tahun 2012

\begin{tabular}{|c|c|c|c|c|c|}
\hline Kabupaten/Kota & $\begin{array}{l}\text { Rawan } \\
\text { Pangan }\end{array}$ & $\begin{array}{l}\text { Kurang } \\
\text { Pangan }\end{array}$ & $\begin{array}{l}\text { Rentan } \\
\text { Pangan }\end{array}$ & $\begin{array}{c}\text { Tahan } \\
\text { Pangan }\end{array}$ & Total \\
\hline Kab. Bogor & 14,63 & 16,90 & 26,48 & 41,99 & 100 \\
\hline Kab. Sukabumi & 16,63 & 10,83 & 44,49 & 28,05 & 100 \\
\hline Kab. Cianjur & 20,22 & 9,72 & 47,11 & 22,96 & 100 \\
\hline Kab. Bandung & 12,11 & 17,34 & 33,67 & 36,88 & 100 \\
\hline Kab. Garut & 26,97 & 15,13 & 37,78 & 20,11 & 100 \\
\hline Kab. Tasikmalaya & 31,12 & 15,08 & 37,87 & 15,93 & 100 \\
\hline Kab. Ciamis & 12,65 & 6,33 & 54,08 & 26,94 & 100 \\
\hline Kab. Kuningan & 12,84 & 4,72 & 54,65 & 27,79 & 100 \\
\hline Kab. Cirebon & 15,15 & 10,99 & 47,52 & 26,34 & 100 \\
\hline Kab. Majalengka & 13,10 & 6,55 & 51,03 & 29,31 & 100 \\
\hline Kab. Sumedang & 9,93 & 4,02 & 49,76 & 36,29 & 100 \\
\hline Kab. Indramayu & 12,13 & 3,39 & 61,05 & 23,43 & 100 \\
\hline Kab. Subang & 13,44 & 7,72 & 39,47 & 39,37 & 100 \\
\hline Kab. Purwakarta & 7,84 & 8,24 & 44,32 & 39,59 & 100 \\
\hline Kab. Karawang & 13,23 & 10,51 & 35,70 & 40,56 & 100 \\
\hline Kab. Bekasi & 9.75 & 18.74 & 24.74 & 46.77 & 100 \\
\hline Kab. Bandung Barat & 28,62 & 20,35 & 29,49 & 21,55 & 100 \\
\hline Kota Bogor & 13,27 & 24,49 & 24,21 & 38,03 & 100 \\
\hline Kota Sukabumi & 15,52 & 20,00 & 30,17 & 34,31 & 100 \\
\hline Kota Bandung & 8,73 & 29,32 & 17,77 & 44,18 & 100 \\
\hline Kota Cirebon & 15,41 & 39,61 & 13,62 & 31,36 & 100 \\
\hline Kota Bekasi & 7,60 & 26,20 & 19,60 & 46,60 & 100 \\
\hline Kota Depok & 7,73 & 25,32 & 16,31 & 50,64 & 100 \\
\hline Kota Cimahi & 7,51 & 20,52 & 19,65 & 52,31 & 100 \\
\hline Kota Tasikmalaya & 18,18 & 23,18 & 28,18 & 30,45 & 100 \\
\hline Kota Banjar & 12,30 & 9,72 & 43,25 & 34,72 & 100 \\
\hline Jawa Barat & 14,64 & 15,20 & 36,16 & 34,00 & 100 \\
\hline
\end{tabular}

Sumber: Susenas 2012 (diolah) 


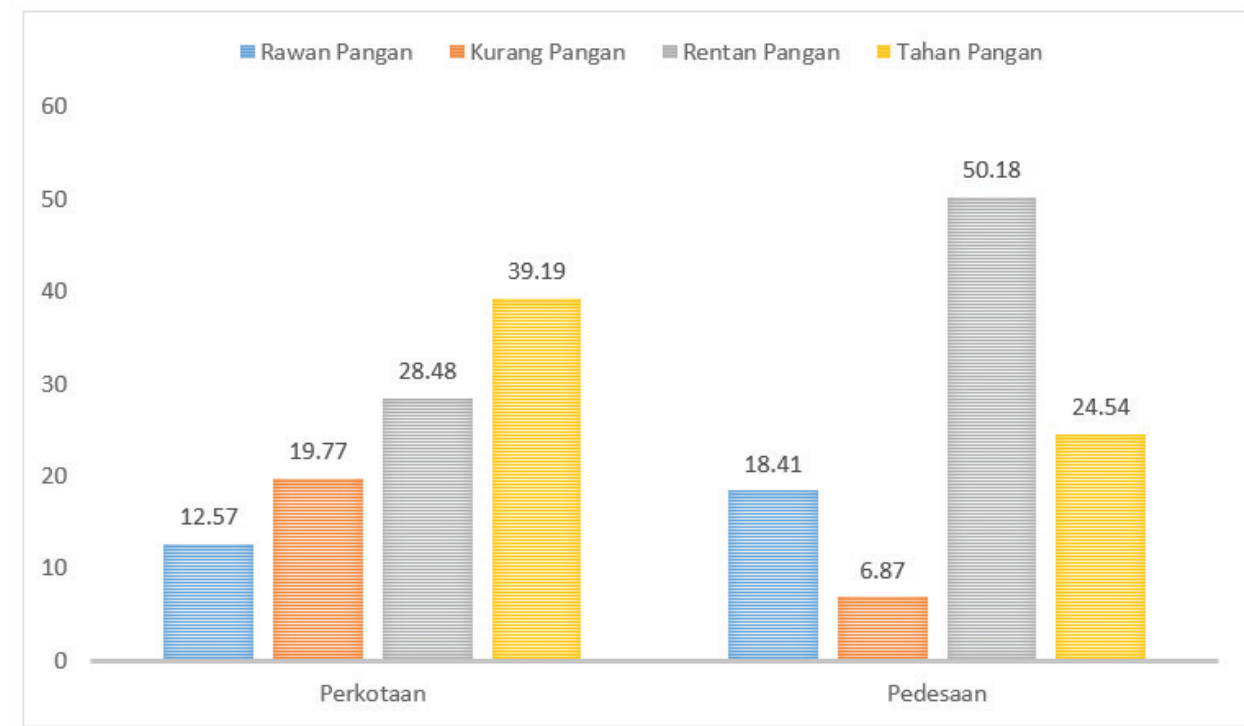

Sumber: Susenas 2012 (diolah)

Gambar 2 Persentase Rumah Tangga dengan Kategori Ketahanan Pangan di Jawa Barat berdasarkan Kategori Wilayah Tahun 2012

Berdasarkan kategori perkotaan dan perdesaan, di daerah perkotaan di Jawa Barat proporsi terbanyak adalah rumah tangga yang tahan pangan $(39,19$ persen) dan rumah tangga dengan kategori rawan pangan merupakan rumah tangga dengan proporsi terendah (12,57 persen). Sementara itu, untuk daerah perdesaan, rumah tangga yang tahan pangan tidak sampai mencapai seperempat dari populasi rumah tangga perdesaan. Akan tetapi, proporsi dari rumah tangga yang rentan pangannya mencapai setengah dari populasi rumah tangga di perdesaan.

Jika dilihat secara umum, kondisi ketahanan pangan di perdesaan di Provinsi Jawa Barat masih lebih baik jika dibandingkan dengan perkotaan karena proporsi dari rumah tangga tahan dan rentan pangan mencapai 75 persen dari populasi, sedangkan yang kurang dan rawan pangan hanya mencapai seperempatnya. Sementara itu, di perkotaan, walaupun proporsi terbesarnya adalah rumah tangga yang tahan pangan, proporsi dari mereka yang kurang dan rawan pangan mencapai 32 persen.

\section{AHFSI FAO}

Berdasarkan aggregate household food security index (AHFSI), Provinsi Jawa Barat tahun 2012 termasuk kategori dengan ketahanan pangan yang rendah dengan indeks sebesar 70,16 . Tidak jauh berbeda dengan gambaran secara umum, AHFSI berdasarkan perkotaan dan perdesaan juga menunjukkan bahwa baik di perkotaan maupun perdesaan di Jawa Barat, level ketahanan pangannya berada di level rendah.

Berdasarkan AHFSI, tidak ada satu pun kabupaten/kota di Jawa Barat tahun 2012 yang mempunyai indeks ketahanan pangan yang tinggi karena mayoritas berada pada ketahanan pangan dengan level yang rendah. Sementara itu, Kabupaten Tasikmalaya, Kabupaten Bandung Barat, Kota Cirebon, dan Kota Tasikmalaya mempunyai indeks ketahanan pangan yang berada pada level kritis. Selain itu, terdapat tujuh kabupaten/ kota dengan level cukup, yaitu Kabupaten Ciamis, Kabupaten Kuningan, Kabupaten Majalengka, Kabupaten Sumedang, Kabupaten Indramayu, Kabupaten Subang, dan Kabupaten Purwakarta. 
Tabel 4 AHFSI di Jawa Barat Tahun 2012 berdasarkan Kategori Kabupaten/Kota

\begin{tabular}{|c|c|c|}
\hline Kabupaten/Kota & AHFSI & Keterangan \\
\hline Kab. Bogor & 69,72 & Level Rendah \\
\hline Kab. Sukabumi & 72,37 & Level Rendah \\
\hline Kab. Cianjur & 70,61 & Level Rendah \\
\hline Kab. Bandung & 71,16 & Level Rendah \\
\hline Kab. Garut & 67,06 & Level Rendah \\
\hline Kab. Tasikmalaya & 64,14 & Level Kritis \\
\hline Kab. Ciamis & 77,36 & Level Cukup \\
\hline Kab. Kuningan & 77,55 & Level Cukup \\
\hline Kab. Cirebon & 73,67 & Level Rendah \\
\hline Kab. Majalengka & 75,04 & Level Cukup \\
\hline Kab. Sumedang & 77,70 & Level Cukup \\
\hline Kab. Indramayu & 76,47 & Level Cukup \\
\hline Kab. Subang & 75,09 & Level Cukup \\
\hline Kab. Purwakarta & 77,15 & Level Cukup \\
\hline Kab. Karawang & 73,87 & Level Rendah \\
\hline Kab. Bekasi & 71,51 & Level Rendah \\
\hline Kab. Bandung Barat & 61,49 & Level Kritis \\
\hline Kota Bogor & 65,93 & Level Rendah \\
\hline Kota Sukabumi & 65,97 & Level Rendah \\
\hline Kota Bandung & 65,04 & Level Rendah \\
\hline Kota Cirebon & 59,88 & Level Kritis \\
\hline Kota Bekasi & 65,57 & Level Rendah \\
\hline Kota Depok & 67,12 & Level Rendah \\
\hline Kota Cimahi & 70,09 & Level Rendah \\
\hline Kota Tasikmalaya & 63,76 & Level Kritis \\
\hline Kota Banjar & 73,56 & Level Rendah \\
\hline Jawa Barat & 70,16 & Level Rendah \\
\hline
\end{tabular}

Sumber: Susenas 2012 (diolah)

Tabel 5 AHFSI di Jawa Barat Tahun 2012 berdasarkan Kategori Perkotaan/Perdesaaan

\begin{tabular}{ccc}
\hline Kabupaten/Kota & AHFSI & Keterangan \\
\hline Perkotaan & 69,12 & Level Rendah \\
Pedesaan & 72,06 & Level Rendah \\
\hline
\end{tabular}

Sumber: Susenas 2012 (diolah) 
Analisis Order Logistic Regression

Subbagian ini menampilkan dan membahas hasil regresi dengan metode ordered logistic regression seperti yang telah dijelaskan pada bagian sebelumnya. Variabel dependen adalah ketahanan pangan rumah tangga yang terbagi menjadi empat kategori, yaitu rawan pangan, rentan pangan, kurang pangan, dan tahan pangan. Sementara itu, variabel independennya adalah dummy perkotaan, dummy jenis kelamin dari kepala rumah tangga, dummy status perkawinan dari kepala rumah tangga, umur dari kepala rumah tangga, banyaknya anggota di rumah tangga, rata-rata lama sekolah dari kepala rumah tangga, dummy apakah kepala rumah tangga bekerja atau tidak, rata-rata pengeluaran per kapita dari rumah tangga tersebut (dalam Rp100.000,00), dummy kondisi sanitasi rumah tangga, dan dummy dari kategori kumuh atau tidak. Deskripsi data selengkapnya ditampilkan pada Tabel 6.

Dari Tabel 6 diketahui bahwa jumlah sampel dari data Susenas tahun 2012 untuk Provinsi Jawa Barat adalah 23.079 rumah tangga. Data yang digunakan sebagai dependen variabel dari penelitian ini adalah variabel Kpangan yang merupakan variabel yang bersifat kategori karena 0 mengategorikan bahwa rumah tangga tersebut tergolong rawan pangan, 1 untuk rumah tangga yang kurang pangan, 2 untuk rumah tangga yang rentan pangan, dan 3 adalah kode untuk rumah tangga yang tahan pangan.

Kemudian sepuluh variabel lainnya merupakan variabel independen. Dari statistik data di atas, dapat diketahui bahwa rata-rata umur kepala rumah tangga di Jawa Barat tahun 2012 adalah 47 tahun. Rata-rata jumlah anggota rumah tangga di Jawa Barat antara 3 dan 4 orang. Sementara itu, rata-rata lama pendidikan dari kepala rumah tangga adalah 7,6 tahun.

\section{Analisis Model}

Tabel 7 menampilkan keluaran dari regresi metode order logistic dengan software Stata 12. Dari hasil keluaran tersebut, dapat dilihat bahwa sampel dari penelitian ini adalah 23.079 rumah tangga. Nilai dari Wald chi2 (10) adalah 2661.44 dengan nilai $p$-value sebesar 0.0000 yang mengindikasikan bahwa secara keseluruhan, model yang digunakan dalam penelitian ini signifikan secara statistik.

Di dalam tabel hasil regresi tersebut, terdapat nilai koefisien, robust standard error (nilai standar eror yang telah dibersihkan dari

Tabel 6 Statistik Data

\begin{tabular}{cccccc}
\hline Variable & Obs & Mean & Std. Dev. & Min & Max \\
\hline Kpangan & 23079 & 1.895273 & 1.03274 & 0 & 3 \\
Kota & 23079 & 0.0497422 & 0.2174165 & 0 & 1 \\
Dumjk & 23079 & 0.859656 & 0.3473511 & 0 & 1 \\
Dumkawin & 23079 & 0.0182417 & 0.1338272 & 0 & 1 \\
Umur & 23079 & 47.82538 & 13.72982 & 14 & 98 \\
Art & 23079 & 3.594913 & 1.523907 & 1 & 13 \\
mys1 & 23079 & 7.63092 & 4.329335 & 0 & 22 \\
Dumkerja & 23079 & 0.8341783 & 0.3719286 & 0 & 1 \\
capita100000 & 23079 & 7.518995 & 8.382449 & 0.93062 & 235.6278 \\
Dumsanitasi & 23079 & 0.5682222 & 0.4953346 & 0 & 1 \\
Dumkumuh & 23079 & 0.1312015 & 0.3376279 & 0 & 1 \\
\hline
\end{tabular}

Sumber: Susenas 2012 (diolah) 
masalah heterokedastisitas), z-test, $p$-value dan $95 \%$ confidence interval dari setiap variabel, cutpoint 1 , cutpoint 2 dan cutpoint 3 .

Pada regresi logistik tidak terdapat intercept (konstanta) seperti yang biasa terdapat pada regresi biasa. Akan tetapi, di sini terdapat cupoints yang merupakan pembatas nilai antartiap variabel dependen.

Semua variabel independen (dummy perkotaan, dummy jenis kelamin, dummy status perkawinan, umur kepala rumah tangga, banyaknya jumlah anggota rumah tangga, rata-rata lama sekolah dari kepala rumah tangga, dummy kerja atau tidak, pengeluaran per kapita rumah tangga, dummy kelayakan sanitasi, dan dummy kondisi kumuh) mengindikasikan signifikan secara statistik.

\section{Tes Signifikansi}

$\underline{\text { Uji Multikolinearitas }}$

Dalam pengujian multikolinearitas, nilai korelasi di atas 0,8 mengisyaratkan adanya korelasi yang kuat antar variabel independen. Tabel 8 di bawah adalah keluaran uji korelasi dari data yang digunakan pada penelitian ini. Dari tabel tersebut terlihat bahwa korelasi antarvariabel independen tidak ada yang bernilai di atas 0,8 . Oleh karena itu, dapat ditarik kesimpulan bahwa tidak terdapat masalah multikolinearitas pada variabelvariabel di dalam model.

\section{Tabel 7 Output Regresi Ordered Logit}

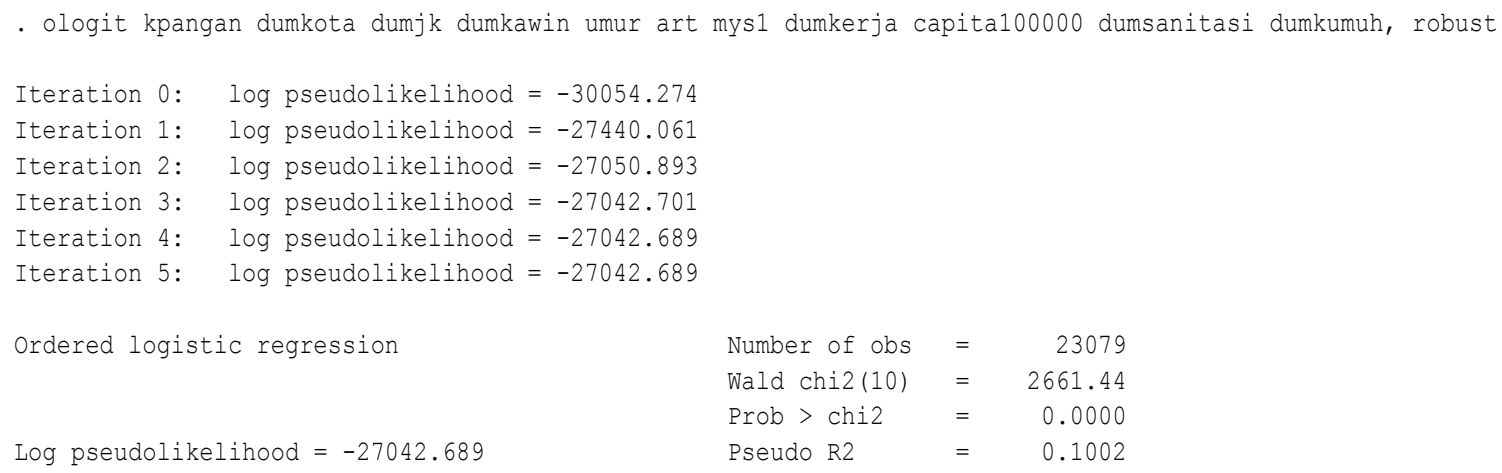

\begin{tabular}{r|rrrrrr}
\hline & \multicolumn{7}{|c}{$\begin{array}{l}\text { Robust } \\
\text { kpangan }\end{array}$} & Coef. & Std. Err. & $\mathrm{z}$ & $\mathrm{P}>|\mathrm{z}|$ & {$[95 \%$ Conf. } & Interval] \\
\hline dumkota & -.1252689 & .0270274 & -4.63 & 0.000 & -.1782416 & -.0722962 \\
dumjk & -.7829468 & .0665733 & -11.76 & 0.000 & -.9134281 & -.6524656 \\
dumkawin & .7154815 & .0630488 & 11.35 & 0.000 & .5919081 & .8390548 \\
umur & .0113398 & .0010604 & 10.69 & 0.000 & .0092614 & .0134182 \\
art & -.2170797 & .0099537 & -21.81 & 0.000 & -.2365886 & -.1975708 \\
mys1 & .0101207 & .0040788 & 2.48 & 0.013 & .0021264 & .018115 \\
dumkerja & .1838811 & .0393592 & 4.67 & 0.000 & .1067386 & .2610237 \\
capita100000 & .1673051 & .0073465 & 22.77 & 0.000 & .1529063 & .1817039 \\
dumsanitasi & .1984996 & .0263694 & 7.53 & 0.000 & .1468166 & .2501826 \\
dumkumuh & -.3985551 & .0357734 & -11.14 & 0.000 & -.4686696 & -.3284406 \\
\hline / cut1 & -1.034759 & .0934859 & & & -1.217988 & -.8515303 \\
/ cut2 & -.0040381 & .0916012 & & & -.1835732 & .175497 \\
/ cut3 & 1.818644 & .0949044 & & & 1.632635 & 2.004653 \\
\hline
\end{tabular}

Note: 24 observations completely determined. Standard errors questionable.

Sumber: Pengolahan Susenas 2012 dengan menggunakan Stata12 
Heryanah

Tabel 8 Output Pengujian Multikolinearitas

\begin{tabular}{|c|c|c|c|c|c|c|c|c|c|c|}
\hline & $\begin{array}{l}\frac{\pi}{0} \\
\underline{0}\end{array}$ & $\stackrel{\leftarrow}{\frac{r}{\alpha}}$ & 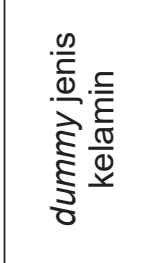 & 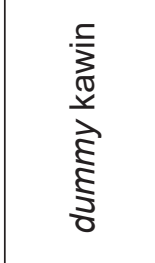 & 站 & 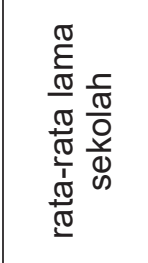 & 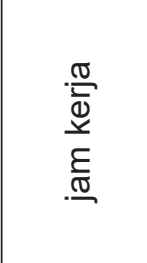 & 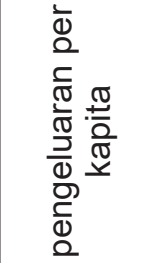 & 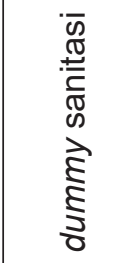 & 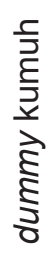 \\
\hline 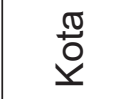 & 1 & & & & & & & & & \\
\hline$\frac{t}{4}$ & 0,072 & 1 & & & & & & & & \\
\hline 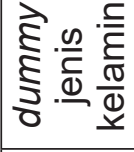 & 0,0192 & 0,2577 & 1 & & & & & & & \\
\hline 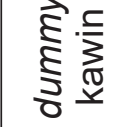 & $-0,0094$ & $-0,189$ & $-0,1069$ & 1 & & & & & & \\
\hline Е & $-0,0317$ & $-0,0458$ & $-0,1376$ & $-0,1513$ & 1 & & & & & \\
\hline 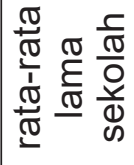 & $-0,0115$ & 0,0886 & 0,1255 & 0,0975 & $-0,3312$ & 1 & & & & \\
\hline 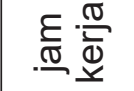 & 0,0161 & 0,0791 & 0,0836 & 0,0147 & $-0,1984$ & 0,1259 & 1 & & & \\
\hline 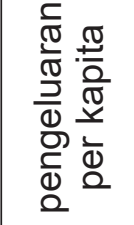 & 0,0246 & $-0,1726$ & $-0,0314$ & 0,1674 & $-0,0333$ & 0,378 & 0,056 & 1 & & \\
\hline 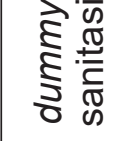 & 0,0462 & 0,0125 & $-0,0191$ & $-0,035$ & 0,036 & $-0,2752$ & $-0,076$ & $-0,234$ & 1 & \\
\hline 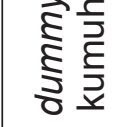 & 0,0192 & 0,2005 & 0,0289 & $-0,0157$ & $-0,0615$ & $-0,1132$ & $-0,0018$ & $-0,1445$ & 0,2199 & 1 \\
\hline
\end{tabular}

Sumber: Pengolahan Susenas 2012 dengan menggunakan Stata12 
1. Uji Serentak

Likelihood Ratio (LR) merupakan pengganti F-statistik yang berfungsi untuk menguji apakah semua variabel independen secara bersama-sama memengaruhi variabel dependen. Pada Tabel 7 diketahui bahwa nilai Wald chi2 test sebesar 2661.44 dengan Prob>chi2 sebesar 0.000 yang mengindikasikan bahwa variabel independen di dalam model secara serentak dapat menjelaskan variabel ketahanan pangan rumah tangga.

\section{Uji Parsial}

Uji parsial untuk setiap variabel independen dapat dilakukan dengan dua cara. Pertama, dengan melihat hasil regresi dan membandingkan nilai $z$ dengan $z$ tabel (atau dengan melihat nilai $p$-value dibandingkan dengan alpha 005). Kedua, dengan menjalankan tes pada setiap variabel independen dan melihat nilai Prob>chi. Jika nilai tersebut lebih kecil dari alpha 0.05, maka Ho ditolak dan berkesimpulan bahwa variabel tersebut secara statistik signifikan memengaruhi variabel dependen. Hasil dari uji parsial dalam penelitian ini adalah sebagai berikut.

Dari semua hasil uji parsial setiap variabel independen, dapat disimpulkan untuk menolak $\mathrm{H}_{0}$ (dimana nilai Prob>chi2 lebih kecil dibandingkan dengan alpha 0.05 ) artinya bahwa setiap variabel independen secara signifikan memengaruhi ketahanan pangan rumah tangga.

\section{Uji Goodness of Fit}

Uji goodness of fit dimaksudkan untuk melihat seberapa tepat suatu model dapat menjelaskan hubungan antara variabel independen dengan variabel dependennya. Dengan kata lain, uji goodness of fit digunakan untuk melihat seberapa besar variasi dari variabel dependen dapat dijelaskan oleh model. Pada regresi logistik, uji goodness of fit dapat dilihat dari nilai Pseudo $\mathrm{R}^{2}$. Dari hasil regresi didapat nilai Pseudo $R^{2}$ sebesar 0.1002 . Hal ini berarti variabel dependen hanya mampu dijelaskan oleh variabel dependen sebesar 10 persen saja. Diduga ada beberapa variabel penting lain yang harus disertakan di dalam model.

\section{Analisis Koefisien dan Odds Ratio}

Koefisien hasil regresi yang ditampilkan pada Tabel 7 menunjukkan arah pengaruh dari variabel indepeden terhadap variabel dependen. Koefisien yang bertanda negatif menunjukkan bahwa variabel independen berhubungan negatif dengan variabel dependen dan sebaliknya. Koefisien tersebut tidak dapat langsung diintepretasikan seperti pada regresi biasa, tetapi harus ditransformasikan menjadi odds ratio. Pada penelitian ini, koefisien yang bertanda negatif adalah variabel dummy perkotaan, dummy jenis kelamin, banyaknya anggota rumah tangga, dan dummy kumuh. Sementara itu, variabel yang bertanda positif adalah dummy kawin, umur KRT, rata-rata lama sekolah, dummy bekerja, pengeluaran per kapita rumah tangga, dan dummy sanitasi. Tabel 9 adalah hasil transformasi koefisien regresi menjadi odds ratio dari penelitian ini.

\section{Analisis Antarvariabel}

Dari hasil regresi didapat bahwa daerah dengan tipe perkotaan cenderung menunjukkan ketahanan pangan rumah tangganya yang lebih rendah (lebih rawan pangan) 0.88 kali daripada rumah tangga di daerah perdesaan. Pada bagian analisis deskripsi sebelumnya, telah disebutkan 
bahwa proporsi rumah tangga yang tahan pangan di daerah perkotaan di Jawa Barat lebih banyak dibandingkan dengan di perdesaan. Tetapi jika digabungkan, proporsi rumah tangga dengan tingkat tahan dan rentan pangan di pedesaan di Provinsi Jawa Barat masih lebih besar jika dibanding dengan perkotaan. Total dari gabungan 2 kategori tersebut mencapai 75 persen dari total rumah tangga pedesaan. Sementara itu, di daerah perkotaan, walaupun proporsi terbesarnya adalah rumah tangga yang tahan pangan, proporsi dari mereka yang kurang dan rawan pangan juga banyak hingga mencapai 32 persen. Dari hasil regresi ini, Pemerintah Daerah Provinsi Jawa Barat harus lebih memperhatikan kondisi di perkotaan. Selain lebih memperhatikan ketersedian pangan yang baik untuk warganya, hal lain yang harus diperhatikan adalah daya beli masyarakat untuk ketersediaan pangan.

Dari hasil regresi didapat bahwa rumah tangga dengan kepala rumah tangga lakilaki cenderung memiliki ketahanan panganan yang lebih rendah (lebih rawan pangan) 0,46 kali daripada rumah tangga yang dikepalai oleh perempuan. Jika dilihat dari jenis kelamin kepala rumah tangga, proporsi perempuan sebagai kepala rumah tangga di Provinsi Jawa Barat tahun 2012 hanya sebesar 13,5 persen, sedangkan sebagian besarnya ( 86,5 persen) dari kepala rumah tangga berjenis kelamin laki-laki. Ketahanan pangan berhubungan erat dengan pengetahuan terhadap pentingnya pangan dan gizi. Temuan penelitian ini menunjukkan bahwa perempuan memegang peran penting dalam memperkuat ketahanan pangan rumah tangganya. Perempuan dapat mengatur perekonomian keluarganya dengan lebih bijak melalui membelanjakan keuangan keluarga sesuai dengan kebutuhan dan kecukupan gizi yang cukup. Di samping itu, perempuan juga dianggap lebih mampu memanfaatkan pekarangan rumahnya untuk ditanam berbagai tanaman. Perempuan juga mampu melakukan diversifikasi pangan untuk keluarganya (Mubarok, 2012).

Dari hasil regresi didapat bahwa rumah tanggayangkepalarumahtangganyaberstatus menikah cenderung lebih tahan pangan 2,05 kali dibandingkan dengan rumah tangga yang KRT-nya berstatus tidak menikah. Selain itu, juga didapat bahwa semakin tua umur kepala rumah tangga, rumah tangga lebih cenderung untuk tahan pangan 1,01 kali. Kedua hal ini berhubungan dengan tingkat kematangan

Tabel 9 Output Odds Ratio dari Regresi Ordered Logit

\begin{tabular}{ccc}
\hline Variabel & Odds Ratio & $\begin{array}{c}\text { Robust } \\
\text { Standard Error }\end{array}$ \\
\hline Kota & 0.882 & $0.024^{* * *}$ \\
Jenis Kelamin & 0.457 & $0.03^{* * *}$ \\
Kawin & 2.045 & $0.129^{* * *}$ \\
Umur & 1.011 & $0.001^{* * *}$ \\
Banyaknya Anggota RT & 0.805 & $0.008^{* * *}$ \\
Rata-rata Lama Sekolah & 1.01 & $0.004^{* * *}$ \\
Kerja & 1.202 & $0.047^{* * *}$ \\
Pengeluaran per kapita & 1.182 & $0.009^{* * *}$ \\
Sanitasi & 1.219 & $0.032^{* * *}$ \\
Kumuh & 0.671 & $0.024^{* * *}$ \\
\hline
\end{tabular}

Sumber: Pengolahan SUSENAS 2012 dengan menggunakan Stata12

Keterangan: ${ }^{* * *}$ Signifikan di $1 \%$ 
dan kedewasaan kepala rumah tangga. Kepala rumah tangga yang menikah dan usianya semakin matang diduga mempunyai tingkat kedewasaan dan kematangan yang lebih baik sehingga mereka dapat lebih bijak dalam mengatur perekonomian, terutama mengatur pola konsumsi dan gizi bagi anggota keluarganya. Oleh karena itu, kedua variabel ini berpengaruh positif terhadap kategori ketahanan pangan dari rumah tangga.

Hasil lain dari hasil regresi adalah ada kecenderungan ketahanan pangan rumah tangga menurun sebesar 0,8 kali setiap jumlah anggota rumah tangga tersebut bertambah. Hal ini sejalan dengan banyak analisis yang mengatakan bahwa banyaknya orang di dalam rumah tangga akan memengaruhi tingkat kesejahteraan rumah tangga tersebut. Semakin banyak jumlah anggota rumah tangga yang harus ditanggung kepala rumah tangga menyebabkan adanya penyesuaian beberapa kebutuhan. Jumlah kenaikan penghasilan yang tidak seimbang dengan banyaknya rumah tangga tentu menyebabkan beberapa kebutuhan tidak dapat terpenuhi dengan baik.

Kecenderungan rumah tangga untuk tahan pangan akan naik sebesar 1,01 kali dengan bertambahnya rata-rata lama sekolah dari kepala rumah tangganya. Pendidikan diyakini merupakan salah satu jalan untuk mendapatkan pengetahuan dan keterampilan. Pada akhirnya mereka dengan pendidikan yang memadai dapat memasuki dunia kerja yang baik dan mendapatkan penghasilan yang memadai. Sementara itu, kepala rumah tangga yang tidak mempunyai pendidikan yang memadai akan memiliki peluang yang kecil untuk mendapat pekerjaan yang baik. Mereka pada akhirnya menerima pekerjaan apa saja guna memenuhi kebutuhan hidupnya. Banyak kepala rumah tangga yang pada akhirnya hanya dapat tertampung pada pekerjaan di sektor informal.

Hasil tabulasi data Susenas tahun 2012 menunjukkan bahwa di wilayah perkotaan
Jawa Barat, mayoritas kepala rumah tangga bekerja di sektor perdagangan. Proporsi rumah tangga tahan pangan yang kepala rumah tangganya bekerja di sektor perdagangan mencapai 24,03 persen dan mayoritas rumah tangga yang rawan pangan juga bekerja di sektor perdagangan dengan proporsi sebesar 19,58 persen. Sementara itu, di wilayah perdesaan, mayoritas bekerja di sektor pertanian. Proporsi rumah tangga rawan pangan yang bekerja di sektor pertanian mencapai sepertiga dari total rumah tangga rawan pangan di perdesaan. Diduga mereka yang bekerja di sektor pertanian adalah bukan para pemilik lahan pertanian, tetapi banyak dari mereka adalah penyewa lahan untuk digarap dan juga kuli penggarap yang bekerja pada musim-musim tertentu dengan sistem penggajian sesuai dengan banyaknya hari kerja.

Rumah tangga yang kepala rumah tangganya bekerja cenderung akan tahan pangan sebesar 1,2 kali dibandingkan dengan jika kepala rumah tangganya tidak bekerja. Di sini terlihat bahwa masalah ketahanan pangan rumah tangga sangat berhubungan erat dengan daya beli rumah tangga tersebut. Kepala rumah tangga yang bekerja akan meningkatkan daya beli dari rumah tangga tersebut untuk memenuhi kebutuhan pangan mereka tidak hanya dari segi kuantitas, tetapi juga dari segi kualitas pangan mereka. Pada akhirnya rumah tangga dengan kepala rumah tangga yang bekerja akan lebih tahan pangan dibandingkan dengan rumah tangga yang kepala rumah tangganya tidak bekerja. Selain itu, dari hasil penelitian ini didapat bahwa kecenderungan rumah tangga untuk tahan pangan akan naik sebesar 1,2 kali dengan setiap kali bertambahnya pengeluaran per kapita rumah tangga tersebut.

Rumah tangga dengan kondisi sanitasi yang layak juga memiliki kecenderungan tahan pangan sebesar 1,2 kali dibandingkan dengan rumah tangga dengan kondisi sanitasi tidak layak. Rumah tangga dengan 
kondisi status rumah tempat tinggal kumuh memiliki kecenderungan tidak tahan pangan (cenderung rawan pangan) sebesar 0,7 kali dibandingkan dengan rumah tangga dengan kondisi rumah tangga yang tidak kumuh.
Hasil regresi ini menguatkan temuan bahwa rumah tangga dengan ketahanan pangan yang tinggi atau rendah dapat terlihat juga dari kondisi lingkungan dan sanitasi yang kumuh.

\section{Tabel 10 Persentase Lapangan Pekerjaan dari Kepala Rumah Tangga di Provinsi Jawa Barat berdasarkan Wilayah dan Status Ketahanan Pangannya}

\begin{tabular}{|c|c|c|c|c|c|c|c|c|}
\hline \multirow[b]{2}{*}{$\begin{array}{l}\text { Lapangan } \\
\text { Pekerjaan }\end{array}$} & \multicolumn{4}{|c|}{ Perkotaan } & \multicolumn{4}{|c|}{ Pedesaan } \\
\hline & 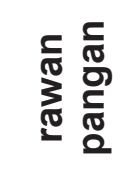 & 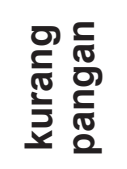 & 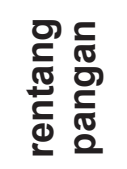 & 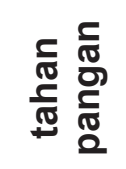 & 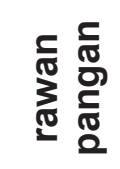 & 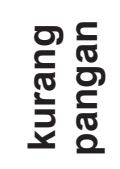 & 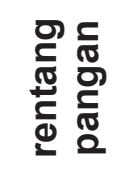 & 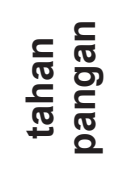 \\
\hline pertanian & & & & & & & & \\
\hline $\begin{array}{l}\text { tanaman padi dan } \\
\text { palawija }\end{array}$ & 11,50 & 5,41 & 13,32 & 5,15 & 36,04 & 25,03 & 37,24 & 24,30 \\
\hline holtikultura & 1,34 & 0,70 & 1,78 & 0,81 & 3,24 & 2,00 & 3,55 & 2,44 \\
\hline perkebunan & 0,70 & 0,50 & 1,21 & 0,72 & 3,24 & 3,86 & 2,70 & 2,37 \\
\hline perikanan & 1,16 & 0,42 & 1,12 & 0,65 & 0,88 & 2,84 & 1,60 & 1,42 \\
\hline peternakan & 0,86 & 0,69 & 1,24 & 0,69 & 1,33 & 1,39 & 2,97 & 297 \\
\hline $\begin{array}{l}\text { kehutanan dan } \\
\text { pertanian lainnya }\end{array}$ & 0,33 & 0,11 & 0,14 & 0,18 & 1,62 & 0,61 & 0,99 & 1,04 \\
\hline $\begin{array}{l}\text { pertambangan } \\
\text { dan penggalian }\end{array}$ & 1,57 & 0,77 & 1,25 & 1,25 & 2,28 & 1,48 & 1,70 & 1,52 \\
\hline $\begin{array}{l}\text { industri } \\
\text { pengolahan }\end{array}$ & 16,55 & 18,74 & 17,94 & 20,80 & 8,26 & 9,26 & 9,04 & 11,09 \\
\hline listrik dan gas & 0,32 & 0,70 & 0,43 & 0,78 & 0,38 & 0,20 & 0,14 & 0,27 \\
\hline $\begin{array}{l}\text { konstruksi/ } \\
\text { bangunan }\end{array}$ & 14,43 & 8,48 & 11,75 & 7,09 & 14,72 & 11,76 & 9,61 & 8,63 \\
\hline perdagangan & 19,58 & 24,06 & 21,52 & 24,03 & 13,67 & 20,07 & 13,65 & 19,83 \\
\hline $\begin{array}{l}\text { hotel dan rumah } \\
\text { makan }\end{array}$ & 2,33 & 2,07 & 2,01 & 2,38 & 0,64 & 2,24 & 0,94 & 0,84 \\
\hline $\begin{array}{l}\text { transportasi dan } \\
\text { pergudangan }\end{array}$ & 10,90 & 8,97 & 8,84 & 6,05 & 5,49 & 7,59 & 6,32 & 4,91 \\
\hline $\begin{array}{l}\text { informasi dan } \\
\text { komunikasi }\end{array}$ & 0,20 & 1,34 & 0,43 & 1,21 & 0,07 & 0,18 & 0,10 & 0,28 \\
\hline $\begin{array}{l}\text { keuangan dan } \\
\text { asuransi }\end{array}$ & 0,63 & 1,60 & 0,53 & 2,24 & 0,20 & 0,30 & 0,17 & 0,63 \\
\hline jasa pendidikan & 1,03 & 3,60 & 1,96 & 4,39 & 0,64 & 2,52 & 1,15 & 4,84 \\
\hline $\begin{array}{l}\text { jasa kesehatan } \\
\text { jasa }\end{array}$ & 0,22 & 1,00 & 0,59 & 1,46 & 0,12 & 0,30 & 0,23 & 0,51 \\
\hline $\begin{array}{l}\text { kemasyarakatan, } \\
\text { pemerintahan dan } \\
\text { perorangan }\end{array}$ & 14,80 & 18,93 & 12,37 & 18,42 & 6,16 & 8,39 & 7,31 & 10,99 \\
\hline Lainnya & 1,55 & 1,91 & 1,59 & 1,72 & 1,02 & 0,00 & 0,59 & 1,12 \\
\hline
\end{tabular}

Sumber: Susenas 2012 (diolah) 


\section{Kesimpulan dan Saran}

Dari hasil olahan data Susenas tahun 2012 diketahui bahwa kondisi ketahanan pangan rumah tangga masih harus menjadi pokok perhatian Pemerintah Daerah Provinsi Jawa Barat. Rumah tangga dengan kategori tahan pangan hanya mencapai 34 persen dari populasi penduduk Jawa Barat, sedanngkan sebagian besar rumah tangga di Jawa Barat masih dalam kategori rentan pangan. Yang lebih mengkhawatirkan adalah, bahkan 15 persen rumah tangga di Jawa Barat berada dalam kondisi rawan pangan.

Jika dianalisis berdasarkan kabupaten dan kota, Kota Cimahi dan Kota Depok merupakan wilayah tingkat II di Jawa Barat dengan proporsi rumah tangga tahan pangannya terbanyak. Kemudian Kabupaten Tasikmalaya dan Kabupaten Bandung Barat merupakan kabupaten dengan proporsi rumah tangga tergolong rawan pangan terbanyak.

Selanjutnya jika dianalisis berdasarkan daerah perkotaan dan perdesaan, kondisi ketahanan pangan di perdesaan di Provinsi Jawa Barat masih lebih baik jika dibandingkan dengan perkotaan. Hal ini karena proporsi dari rumah tangga tahan dan rentan pangan mencapai 75 persen dari populasi, sedangkan yang kurang dan rawan pangan hanya mencapai seperempatnya. Sementara itu, di perkotaan, walaupun proporsi terbesarnya adalah rumah tangga yang tahan pangan, proporsi dari mereka yang kurang dan rawan pangan mencapai 32 persen.

Dari kesepuluh faktor-faktor yang diduga memengaruhi ketahanan pangan rumah tangga di Jawa Barat, ditemukan bahwa semua faktor ini secara bersama-sama (simultan) maupun secara parsial signifikan memengaruhi ketahanan pangan rumah tangga.

\section{Daftar Pustaka}

FAO. 1996. World Food Summit, 13-17 November 1996. Rome, Italy: Food and Agriculture Organization of the United Nations.

Gujarati, Damodar N. 2003. Basic Econometrics. McGroe-Hill education. Fourth Edition.

Heryanah. 2014. "Ketahanan Pangan Rumah Tangga di Provinsi Jawa Barat: Analisa Faktor yang Mempengaruhinya". Paper Diklat Fungsional (tidak diterbitkan).

Jonsson, U. and D. Toole. 1991. Household Food Security and Nutrition: A Conceptual Analysis. New York: United Nations Children's Fund.

Mubarok. 2012, "Perempuan dan Katahanan Pangan Keluarga,"http://www.kompasiana. com/mubarokkom01/perempuan-danketahanan-pangan-keluarga_551803b4a 333117d07b6621f. Diunduh pada 30 April 2017, pukul 11.00 WIB.

Oxfam. 2001. The Impact of Rice Trade Liberalization on Food Security in Indonesia. A study conducted for OxfamGreat Britain.

Peraturan Daerah Provinsi Jawa Barat Nomor 22 Tahun 2008, "Organisasi dan Tata Kerja Inspektorat, Badan Perencanaan Pembangunan Daerah, Lembaga Teknis Daerah dan Satuan Polisi Pamong Praja Provinsi Jawa Barat"

Praptono, A. 2009. "Penerapan Metode Regresi Logistik pada Sampling Kompleks". Tesis Program Pascasarjana Universitas Padjadjaran.

UU No. 7 Tahun 1996 tentang Pangan. 